\title{
Financing and performance of female-owned firms in Middle Eastern and African Economies
}

Complutense

de Análisis

Económico

\section{Mina Baliamoune-Lutz}

University of North Florida, Coggin College of Business, 1 UNF Drive, Jacksonville, FL 32224, USA

\section{Stefan Lutz}

European Management School (EMS), Professorship for Economics, Rheinstrasse 4N, Mainz, 55116, Germany

\begin{abstract}
Empirical evidence suggests that lack of access to financing is a major constraint to performance by female-owned firms in most countries. Firm performance, financing structure, and constraints have been well explored for firms in developed economies but this is not the case for firms in developing economies, especially in Africa and the Middle-East. Largely due to lack of data availability, existing literature on African firms has presented some survey-based evidence on firm performance and financing structures while detailed financial evidence is lacking. This paper aims at filling this research gap. We identify female-owned firms and examine the impact of ownership structure on financing and firm performance. We use cross-sectional financial data covering 25,500 companies in the Middle East and Africa for the years 2006 to 2014. Our results reveal a clear, but perhaps surprising, gender-specific pattern.
\end{abstract}

Keywords gender, ownership, firm profitability, financing structure, MENA, Africa, FDI, globalization

JEL Classification F20, J16, L22, M10

\section{Working Paper no 1709}

February, 2017

UNIVERSIDAD

COMPLUTENSE

MADRID

ISSN: 2341-2356

WEB DE LA COLECCIÓN: http://www.ucm.es/fundamentos-analisis-economico2/documentos-de-trabajo-del-icaeWorking papers are in draft form and are distributed for discussion. It may not be reproduced without permission of the author/s. 


\title{
Financing and performance of female-owned firms in Middle Eastern and African Economies*
}

\author{
Mina Baliamoune-Lutz ${ }^{1}$ and Stefan Lutz ${ }^{2}$ \\ This draft: February 1, 2017
}

\begin{abstract}
Empirical evidence suggests that lack of access to financing is a major constraint to performance by female-owned firms in most countries. Firm performance, financing structure, and constraints have been well explored for firms in developed economies but this is not the case for firms in developing economies, especially in Africa and the Middle-East. Largely due to lack of data availability, existing literature on African firms has presented some survey-based evidence on firm performance and financing structures while detailed financial evidence is lacking. This paper aims at filling this research gap. We identify female-owned firms and examine the impact of ownership structure on financing and firm performance. We use crosssectional financial data covering 25,500 companies in the Middle East and Africa for the years 2006 to 2014. Our results reveal a clear, but perhaps surprising, gender-specific pattern.
\end{abstract}

JEL classification: F20, J16, L22, M10

Keywords: gender, ownership, firm profitability, financing structure, MENA, Africa, FDI, globalization

\footnotetext{
* The authors would like to thank the Faculty of Management Technology at the German University in Cairo for its support. Lutz is also grateful for support by the Instituto Complutense de Analisis Economico at Universidad Complutense de Madrid, Spain.

${ }^{1}$ University of North Florida, Coggin College of Business, 1 UNF Drive, Jacksonville, FL 32224, USA, mbaliamo@ unf.edu, +1 9046201223.

2 European Management School (EMS), Professorship for Economics, Rheinstrasse 4N, Mainz, 55116, Germany, lutz@uel.ac.uk, +49 15146672069.
} 


\section{Introduction and overview}

According to research by the World Bank (2011) there is a clear positive correlation between gender equality and GDP per capita, the level of competitiveness and human development. This is particularly true in the Middle East and Africa where female firm ownership and management is markedly low and female firm owners still face a variety of gender-specific obstacles. ${ }^{3}$

While firm performance is affected by many factors, including the legal environment, corruption, political stability, and infrastructure, there is also evidence that ownership and manager characteristics have major effects on individual firm performance. While this has been well explored for firms in developed economies this is not the case for firms in developing economies. ${ }^{4}$

In particular, the role of female ownership in firm performance in the Middle East and Africa remains to be investigated in detail. Empirical evidence so far suggests women managers may increase individual firm performance (Dezsô and Ross, 2012; Smith et al., 2006). On the other hand, female firm owners face a variety of obstacles such as lack of access to financing. While access to financing is a critical issue for many African and Middle Eastern firms ${ }^{5}$, this is particularly the case for female-owned firms. ${ }^{6}$

Largely due to lack of data availability existing literature on Middle eastern and African firms has presented anecdotal and survey-based evidence on firm performance and financing structures while detailed financial evidence (from balance sheets and profit/loss statements) is still lacking.

This paper aims at filling this research gap. We identify the ownership type of firms and examine the impact of ownership structure on financing structure and firm performance. Financing structure is measured by available equity finance and the ratio of debt to equity. Firm performance is represented by sales, profits, and returns. Other firm characteristics include a measure of risk (volatility of profits) and firms are distinguished by country and industry. Ownership types are derived from the identity of the global ultimate owner and includes the gender of individual owners. Ownership information includes, besides gender, several other attributes of the ultimate global firm owner such as state or private ownership, family ownership, number of owners, ownership concentration, form of consolidation, and degree of independence.

We use cross-sectional financial reporting data of 25,500 companies in the Middle East and Africa for the years 2006 to 2014. Data source is Bureau van Dijk's Orbis database.

Our data reveal a clear gender-specific pattern. The share of female-owned firms in the Middle East and Africa is approximately four percent on average. This share varies widely between countries but much less across industries. Female-owned firms have on average lower sales, profits and returns on equity. They also have lower levels of equity and debt capital and a lower leverage (gearing); i.e., ratios of debt to equity.

Our results also reveal a clear gender-specific pattern. Increased availability of equity and/or debt capital as well as higher leverage have significantly positive effects on firm performance,

\footnotetext{
${ }^{3}$ See, for example, Ahl (2006), Baliamoune-Lutz (2016), Baliamoune-Lutz (2015), Baliamoune-Lutz and McGillivray (2009), Hallward-Driemeier (2013), Minniti (2010).

${ }^{4}$ See Baliamoune-Lutz (2011), Brixovia (2010), Painter and Dobie (2010), Rogerson (2000), Rugraff and Hansen (2008), Tarek and Mohamed (2008).

${ }^{5}$ See, for example, Quartey (2003), Rocha et al. (2011).

${ }^{6}$ Asiedu et al. (2013).
} 
measured by sales, profits and returns on equity. Female ownership per se appears to significantly lower firm performance according to all measures used even when we control for the levels of available capital and the degrees of leverage. However, when the interaction of ownership with capital availability is taken into account, the effects change significantly.

The remainder of the paper is structured as follows. Section 2 provides a discussion of the relevant literature. Section 3 describes the data used. Section 4 presents the general modeling and summarizes the results. Section 5 suggests a theoretical explanation. Section 6 concludes. Statistical and econometric results are presented in the appendix.

\section{Review of relevant literature}

Evidence from both theoretical and empirical literature suggests that factors related to firm characteristics (such as age and size of the firm, and industry type) and owner/manager attributes (such as age and education, gender, and social connections and membership in networks) can determine the ability to access credit/finance (Majed, 2010; Sorooshian, 2010). These factors, in general, tend to favor male over female-owned firms, although the evidence remains somewhat mixed. Studies have documented that there is a female-male gap at market entry and women-owned firms tend to be smaller in size, younger and disproportionately operating in low-profitability and low-growth sectors or industries, and that undercapitalization is a major contributor to this outcome (Kelly et al,. 2013; World Bank, 2011; National [US] Women's Business Council, 2015).

In the following review of relevant studies, we summarize findings reported primarily in the empirical literature and related to our main focus in the empirical section of the paper: access to finance and gender, as determinant of firm performance. The main hypothesis being that because relative to their male counterparts, women firm owners/managers are generally younger, less educated, with younger and smaller firms and are in sectors that are traditionally less attractive to men (lower-risk and lower-profitability businesses), they have lower access to finance.

\subsection{Firm characteristics and access to credit/finance}

\subsubsection{Firm's age}

Some aspects related to the firm's age, such as reputation and the size of tangible assets, can reduce or mitigate the problem of information asymmetry (Berger and Udell, 1998; Pandula, 2011; Serrasqueiro and Nunes, 2012; Abdulsaleh and Worthington 2013) and thus can reduce the cost of financing (pecking order theory). Serrasqueiro and Nunes (2012) study Portuguese firm-level panel data and find that a firm's age "is relevant for: the impact of financial deficit on variations of short- and long-term debt; the level of adjustment of short- and long-term debt toward the respective optimal levels; and the relationships between usual determinants and short- and long-term debt."

\subsubsection{Firm size}

Large firms tend to be better positioned, relative to small firms, to access finance, especially external finance. An important reason for this easier access is the documented positive link between size and productivity and growth. For example, using data from eight European countries, Pagano and Schivard (2003) find that larger firm size has a positive impact on 
productivity growth through allowing firms to benefit from R\&D-induced higher returns. A number of empirical studies have used firm size, typically represented by total assets, and found that size matters for access to external finance. For example, using data from U.K. manufacturing firms over the period from 1989-1999, Bougheas et al. (2006) find that size (along with firm's age and profitability) is a major determinant of access to short-term and long-term credit.

Kumar and Francisco (2005) use data from Brazil and find that firm's size is a major determinant of access to credit and credit constraints. The authors find that "[1]arge and medium firms are more likely to have a loan, and less likely to have credit constraints...size appeared to have a much more significant effect on determining access to credit than performance-related variables... there is an effective quantitative limit in the allocation of credit to smaller sized borrowers" (Kumar and Francisco, 2005, p.20). Similarly, the impact of firm's size on access to finance has been documented in Gertler and Gilchrist (1994), Kashyap et al. (1996), and Atanasova and Wilson (2004) and the findings generally show that the firm's access to non-bank debt and long-term debt has a positive correlation with firm's size. The role of size in easing credit/finance constraints has also been identified in the case of 16 African countries studied by Kounouwewa and Chao (2011). Using survey data covering 1559 firms, the authors report that size and foreign ownership are important determinants of financial obstacles facing firms. ${ }^{7}$

\subsubsection{Industry sector}

Some theoretical studies postulate that industry classification can represent (proxy for) business risk (Hall et al., 2000; Barbosa and Moraes, 2003) and thus influence the firm's access to debt financing. Firms operating in whole sale and retail industries were found to have weakest asset and debt ratio structures while firms in the agricultural industry were found to have strongest asset and capital structures (Abor, 2007). However, a study using a large sample of firm data from Spain (González et al., 2007) finds that the industry sector (manufacturing versus service firms) did not have any impact on firms' access to external finance.

On the other hand, Kuntchev et al. (2012) found regional differences in the impact of industry type on financial constraints. Using firm-level data from Enterprise Surveys, the authors report that in Eastern Europe \& Central Asia and Latin America \& Caribbean countries "the distributions of the credit constrained status within the 3 sectors (manufacturing, retail and other services) are very similar"; in East-Asia and Pacific "manufacturing firms are more likely to be credit constrained" and in South Asia, the strongest credit constraints were faced by the retail sector, While in Africa, firms in the 'other services' sector faced the least credit constraints.

\subsection{Effects of owner/manager attributes}

\subsubsection{Owner/manager's age}

Using a sample of 87 manufacturing SMEs from Asmara City in Eritrea, Ogubazghi and Muturi (2014) find that while both the age and education of managers/owners have positive

\footnotetext{
7 It is worth noting that causality may also run from financial constraints to firm size. For theoretical models explaining this relationship, see for example, Cooley and Quadrini (2001) and Cabral and Mata (2003). Also, see Angelini and Generale (2005) for empirical evidence based on Italian firm-level data.
} 
effects on access to bank loans, only the effect of age is significant. Age can influence the owner/manager's (especially in the case of SMEs) decision to use or not use bank loans (demand side effects of age) either as a result of age-related attitude towards risk or as a result of age-related differences in the motivation to become entrepreneur/business owner which varies (Nakano and Nguyen 2011; Abdulsaleh and Worthington 2013), or both.

It worth noting that age is also a major factor on the supply side of finance, since banks view younger and older firm owners/managers differently. While young owners/managers can be perceived as risky, old ones can be viewed as non-dynamic and non-innovative.

\subsubsection{Owner/manager's education}

A number of studies have argued that banks consider more educated firm owners or managers as more creditworthy (Abdulsaleh and Worthington 2013; Ogubazghi and Muturi, 2014). The level of education of the firm's owner/manager can have a significant effect in improving access to finance although some studies found that the effect of educational levels was not significant (see, for example, Ogubazghi and Muturi, 2014). The assumption (especially in the case of SMEs) underlying the positive effect of owner/manager's educational level on access to finance is that educational level is positively correlated with firm performance (Kasseeah and Thoplan, 2012). Tertiary education, in particular, has been shown to have a significant influence on easing access to bank capital (Bates, 1990). However, some studies have noted a negative relationship between owner/manager's educational level and/or skills and access to access to credit; for example, Le et al. (2006) in the case of Vietnamese firms.

\subsubsection{Gender and access to finance}

Numerous studies have documented the significant differences between female- and maleowned/managed firms in access to external financing (Carter and Rosa, 1998; Haines et al., 1999; Coleman, 2000 and 2007; Brush et al., 2001; Greene et al., 2001). These differences tend to be due not only to historical (male-owned firms are traditionally older) and cultural factors (Gupta et al., 2009 and 2013; Shinnar et al., 2012) but also to differences in access to education, networks, high-profit and high-growth industries and age demographics. Thus, the factors reviewed earlier seem to have an amplified influence on female-owned (or managed) firms. Since women, especially in developing countries, tend to be less educate and less finance literate (Baydas et al, 1995; Tsai, 2004; Marlow and Patton, 2005), they face greater constraints in accessing formal finance. ${ }^{8}$ This is in particular the case in sub-Saharan Africa and some of the MENA countries - the regional focus of this paper-where there is empirical evidence of lower start-up capital for women-owned businesses. For example, Brixiová and Kangoye (2016), using data from a survey of entrepreneurs in Swaziland, find that "Women entrepreneurs have smaller start-up capital and are less likely to fund it from the formal sector than their men counterparts, pointing to a possible room for policy interventions." On the other hand, using SME data from Business Environment and Enterprise Performance Surveys, Yaldiz et al. (2011) document "a positive but statistically insignificant association between female ownership and trade credit use."

\footnotetext{
${ }^{8}$ However, Yaldiz et al. (2011), showed that women have more ability to access formal credit and maintain business women can be viewed as better educated and more talented compared to business men because to be able to establish a business in a field that has been traditionally dominated by men women have to have greater levels of education and talent.
} 
Based on data from a large sample of borrowing men and women business owners in Canada, Fabowale et al. (1995) find that "men and women business owners differ in systematic ways, but that when such differences are taken into account, no differences in the terms of credit persist." Furthermore, the authors find that female small business owners "feel themselves to have been treated disrespectfully by lending officers to a significantly greater extent than do male business owners". The findings in the study by Coleman and Carsky (1996) are consistent with these results, since the authors report that a high proportion of US women business owners surveyed have switched banks and that the major reasons included: "poor customer service, an arrogant and condescending attitude on the part of bank personnel, and errors and mistakes." The authors recommend that that bank managers should improve the quality of their interactions with women business owners. A male-female funding gap has also been documented by Alsos et al. (2006) who find that "[w]hile there are few detected gender differences with respect to funding perceptions and behavior, women obtain significantly less financial capital to develop their new businesses. The authors also find that this lower level of financial capital that women obtain is correlated with lower early business growth relative to their male counterparts. Saparito et al. (2013) use 696 matched firm owner/manager-bank manager pairs and show that "male-male pairs of business owner/managers and bankers had the highest levels of trust, satisfaction with credit access, and bank knowledge, while female-female pairs had the lowest levels for each measure; with mixed pairs in the middle on all accounts". This is consistent with the perception of discrimination and disrespect reported by women firm owners/managers (Fabowale et al., 2995; Coleman and Carsky, 1996).

However, Orser et al. (2006) examine gender differences among Canadian SME owners seeking external finance, including commercial debt, leasing, supplier financing, and equity capital find (after controlling for size and industry sector) that "women business owners were equally likely as men to seek all types of external financing, except for external equity capital." The authors also find that, even after controlling for systemic factors, women majority-owned businesses were significantly less likely to seek equity capital but men and women business owners were equally likely to obtain capital when they do apply.

Empirical evidence also shows that women-owned firms tend to export less compared with male-owned firms, even in developed countries. For example, Orser et al. (2010) survey a large number of Canadian SMEs and report that after controlling for sector, firm, and owner characteristics, women majority-owned firms were significantly less likely to export than male-owned firms. To the extent that exporting firms have greater access to, and seek more, external finance, this suggests an additional mechanism for women's lower access to external finance.

\section{The Data}

\subsection{The data set}

The data set used in this study presents cross-sectional financial reporting data of companies in the Middle East and Africa. It contains ownership, balance sheet and profit/loss information.

Data source: Bureau van Dijk (BvD); Orbis global firm database; 278,024 firms from Africa and the Middle East; yearly data for 2006-2015; 25,523 firms (9\%) with global owner name; unbalanced panel with average panel depth of 5 years. See Table 1 in the appendix for a summary of the data source and search details. 
Available firm-level data include balance sheet data, profit and loss statement data, trade descriptions, industry and peer group information, ownership information, stock price and firm valuation data. Available ownership information includes name and nationality of global ultimate owner, index variables for female/male/family/state/international ownership, number of owners, BvD independence index (15 different ratings based on ownership concentration and type), percentage of direct and total ownership, and consolidation status of firm.

Further information about the data set is given in the appendix. Table 2 presents a list of variables and their definitions; Table 3.1 presents summary statistics of the variables used. Note that the number of firms and observations is mainly constrained by the available financial data ie revenues, profits etc. Consequently, data estimations contain up to 18,700 observations covering up to 3,600 firms.

\subsection{Data characteristics}

The share of female-owned firms in the Middle East and Africa is approximately about four percent on average. This share varies widely across countries but much less across industries. As Table 3.2 shows, female-ownership shares by country in our data set range from 13 percent in DRC to zero percent in countries such as Malawi, Mozambique, Namibia, Sudan, Uganda, Yemen, Zimbabwe. According to the data shown in Table 3.3, female-ownership shares by industry range from about six percent in construction, wholesale and retail trade to about two percent in agriculture, manufacturing, and media services.

Female-owned firms have on average lower sales, profits and returns on equity. Female-owned firms also have lower levels of equity and debt capital and a lower leverage (gearing); i.e., ratios of debt to equity. Table 3.4 shows that female-owned firms on average have access to less than half of the amount of equity capital compared with other firms and access less than 20 percent of the amount of debt financing relative to other firms. Similarly, female-owned firms on average generate half the sales and less than 20 percent of the profits of other firms.

\section{Modeling and results}

\subsection{Econometric modeling}

Given the panel data available, we can use the following generalized regression model to investigate the economic hypotheses presented:

$$
y_{i, t}=\alpha+\mathrm{B} F_{i}+\Gamma G_{i, t}+\Delta M_{t}+\varepsilon_{i, t}+\eta_{i}
$$

where the dependent variable $y_{i, t}$ is a profit or sales level indicator (sales, profit, return) of company $i$ in period $t ; F_{i}$ is a vector of determinants specific to firm $i$ but invariant over time (such as country or industry); $G_{i, t}$ is a vector of determinants that may vary between firms and also over time (e.g., gearing); $M_{t}$ is a vector of period-specific determinants outside of a particular firm (captured by year); $\varepsilon_{i, t}$ is an idiosyncratic error term that may vary between firms and also over time and is independently distributed with $\mathrm{E}\left(\varepsilon_{i, t}\right)=0$; and $\eta_{i}$ represents unobserved heterogeneity across firms, i.e., a company specific fixed effect or random effect (that is independently distributed). 
This general specification allows for pooled ordinary least squares (OLS), random-effects (RE), and fixed-effects (FE) modeling, where the random or fixed effects are firm-specific components. The more general approach is to allow for random firm-specific effects; the case where these effects are fixed, that is determinate constants instead of random variables, is a special sub-case. All model variants reported below were estimated with OLS pooled models, FE and RE panel models, and instrumental variable (IV) models. Models were also run with controls for years, countries and industries (where appropriate).

The data available contain several firm-specific, time-invariant variables that can be assumed to capture a significant part of present fixed effects (e.g., country, industry indicators). Hence a random-effects specification seems to be a priori more appropriate. However, Hausman tests for FE versus RE modeling undertaken for the models reported below (not reported here) tend to reject the null of consistency in the RE modeling; consequently the reported FE model should be considered more reliable and we also use an instrumental-variable (IV) specification. Nevertheless, all estimations together present a consistent picture and allow for unified conclusions regarding the role of female-owned firms in Africa and the Middle East. Estimation results are summarized below.

\subsection{Results}

Our results are derived from pooled OLS, FE, RE, and RE-IV estimations. In the latter RE-IV estimations we take account of the possibly endogenous nature of female ownership (i.e., that low-performance firms are not normally selected by men and hence may end up being owned by women) by instrumenting female ownership with a number of variables representing intrinsic ownership characteristics. We also take account of differences in the level of risk involved by the chosen businesses.

In a first step, we take a preliminary look at the effect of female-ownership on revenue and profits. Following Lutz (2013), we construct 3-year averages of main right-hand-side (RHS) variables, here previous capital endowments, and use their lagged values as main determinants together with a female-ownership indicator. As Table 4.1 shows, such a simple OLS model explains 50 to 70 percent of variations in revenues and profits (measured in natural logs) and female ownership appears to have a statistically significant negative effect.

An important question arises: Are women less capable entrepreneurs? When we extent the analysis to account for efficiency of use of capital, a different picture emerges. In the augmented models presented in Table 4.2 we use lagged interaction terms between female ownership and the 3-year averages of equity endowments and the gearing (debt/equity) ratios. While female ownership per se still is correlated with lower revenues, profits, and returns, both interaction terms are positive and statistically significant. Apparently, increased availability of equity and/or debt capital as well as higher leverage have significantly positive effects on firm performance. When female-owned firms acquire more equity or debt financing or when they increase their leverage, resulting performance increases are significantly greater than for other firms as indicated by the interaction terms. These preliminary results are confirmed by randomeffects (Table 4.3) and fixed-effects (Table 4.4) estimations. ${ }^{9}$

However, female ownership may be endogenous. Additionally, female entrepreneurs may choose systematically less risky businesses. To address these issues, we instrument female ownership using a risk measure and intrinsic ownership characteristics (ownership concentration, degree of independence) while controlling for other relevant factors (country,

\footnotetext{
${ }^{9}$ Note that Hausman tests reject the null of consistency in the RE modelling; consequently the reported FE model should be considered more reliable or an instrumental-variable (IV) specification should be used.
} 
industry, year, data availability, consolidation status). As a risk measure we use the 3-year standard deviation of profits, which has been shown to be a significant determinant of average future firm performance. As expected, risk has a negative and significant effect on the probability of the firm owner being female; see Table 4.5.

Descriptive statistics presented earlier suggest that female entrepreneurs might be capital constraint since (on average) they have less equity and debt available to operate their firms. Estimating models with determinants of equity and debt, respectively, shown in Table 4.5, confirms this: female ownership has a negative and significant effect on levels of equity and debt.

Finally, Table 4.6 presents RE-IV estimations of the effect of female-ownership on revenue and profits where female ownership is instrumented and variations of individual business risk are taken into account. Obtained results are qualitatively identical to our earlier OLS results: while female ownership per remains correlated with lower revenues, profits, and returns, both interaction terms are positive and statistically significant.

\section{A theoretical explanation}

In what follows, we develop a possible theoretical explanation for the main results presented above. We start with the observation that there is a positive relationship between the riskiness of businesses undertaken and their average return on equity capital employed. The main reason being that capital investors (firm owners) will only accept higher risk if they can expect higher returns on their investment in turn. ${ }^{10}$

Similar to the conventions in the capital-asset pricing theory, the required average return for any business investment $\mathrm{i}, \mathrm{r}$, can be expressed as:

$$
r_{i}=r_{f}+\alpha_{i} \sigma_{C i}\left(\frac{1}{V_{i}}\right)
$$

where $r_{f}$ denotes the risk-free rate of interest, $\alpha_{i}$ is a risk-parameter derived from the capitalasset pricing model, $\sigma_{\mathrm{Ci}}$ is the standard deviation of profits (or cash flow), and $\mathrm{V}_{\mathrm{i}}$ is firm i's market value of equity. Note that $\mu_{\mathrm{i}}=\mathrm{r}_{\mathrm{f}}+\alpha_{\mathrm{i}}\left(\sigma_{\mathrm{Ci}} / \mathrm{V}_{\mathrm{i}}\right)$ and $\sigma_{\mathrm{i}}=\left(\sigma_{\mathrm{Ci}} / \mathrm{V}_{\mathrm{i}}\right)$ denote the expected value and the standard deviation of the rate of return on equity, respectively.

A risk-averse investor will now take the probability of default given the investment's risk and her capitalization into account. Within a single period, the business will default if the total loss from the business exceeds available capital ie:

$$
-r_{i} V_{i} \geq V_{i} L_{i} \Leftrightarrow r_{i} \leq-L_{i}
$$

where $L_{i}$ is firm i's leverage ie the ratio of debt to equity financing.

Under conventional assumptions about the distribution of profits, the probability of default (satisfying equation (3)) is then decreasing when equity capital and/or leverage are increased. This probability $\mathrm{P}($.$) can be expressed by the cumulative distribution function (CDF) of firm$ i's return $\mathrm{F}_{\mathrm{i}}($.$) .$

$$
P\left(r_{i} \leq-L_{i}\right)=F_{i}\left(-L_{i}\right)
$$

\footnotetext{
${ }^{10}$ Lutz (2013), Lutz (2012).
} 
If we assume return to be normally distributed the CDF becomes:

$$
F_{i}\left(-L_{i}\right)=\Phi\left(\frac{-L_{i}-\mu_{i}}{\sigma_{c i} / V_{i}}\right)
$$

where $\Phi($.$) is the CDF of the standard normal distribution.$

Holding $\mathrm{F}_{\mathrm{i}}\left(-\mathrm{L}_{\mathrm{i}}\right)$ constant, eg at $5 \%$, amounts to requiring that the risk of default will not rise above $5 \%$. Investors requiring such a default risk limit would have to seek less risky business investments if either their equity capital $\mathrm{V}_{\mathrm{i}}$ or their leverage $\mathrm{L}_{\mathrm{i}}$ is lowered as equation (5) clearly shows. Choosing alternative business investments with lower profit risk $\sigma_{\mathrm{Ci}}$ will then lead to lower expected returns according to equation (2).

Hence capital-constrained entrepreneurs - those with less access to equity and debt capital and lower leverage rates - choose less risky businesses even if their willingness to accept risks is the same as everybody else's. As a result their businesses are less profitable even though they may utilize available capital more efficiently.

\section{Concluding remarks}

In this study, we present evidence that there is a clear gender-specific pattern revealed by the data that appears to be supported by the econometric investigation. For all firms including female-owned firms, increased availability of equity and/or debt capital as well as higher leverage have significant positive effects on firm performance, measured by sales, profits and returns on equity. Female-owned firms have on average lower sales, profits and returns on equity. And female ownership per se appears to significantly lower firm performance according to all measures used even when we control for the levels of available capital and the degrees of leverage.

However, when the interplay of ownership with capital availability is taken into account, the nature of the impact of women's ownership seems to change. When female-owned firms acquire more equity or debt financing or when they increase their leverage, resulting performance improvement is significantly greater than for other firms. This suggests that female-owned firms would perform better than other firms given the same access to capital. Existing financing constraints appear as a major factor in holding female-owned firm performance back in the Middle East and Africa.

Our results are confirmed by anecdotal evidence. For example, when the EBRD launched the Women in Business programme in Egypt in October 2015 hosted by the National Bank of Egypt, present women entrepreneurs uniformly mentioned lack of capital access as a major concern. Coincidentally, all five Bank representatives present at the conference were male. ${ }^{11}$

Finally, we present a possible theoretical explanation for the results obtained. Female entrepreneurs choose less risky businesses because they are capital-constrained. As a result their businesses are smaller and less profitable even though they may utilize available capital more efficiently.

The results obtained in this paper have important policy implications. First, policymakers should ensure that financial institutions (especially banks)'s decision makers personnel are not

\footnotetext{
${ }^{11}$ EBRD (2015); Lutz attended the conference.
} 
biased against women owners/managers. Specific training as well as greater gender diversity at these institutions may help to achieve this outcome. Second, while policymakers (as a result of recommendations by the World Bank and the African Development Bank through the African Women in Business Initiative) in some African and MENA countries have tried to address the supply-side constraint, there are important demand-side constraints that need to be alleviated. Women's lower use of external finance could also be due to lower demand for it. This lower demand may stem from the fact that women manage the firm while at the same time taking care of children so that firm growth is not a priority. In this case, investing early childhood education and preschool day care could significantly improve women's demand for, and access to, credit and external finance as it would free up women's time and allow them to participate more in training and support networks which should contribute to higher productivity and better performance (World Bank, 2011; Blackden and Hallward-Driemeier, 2013).

Finally, education can play an important role in changing the way society views female-owned businesses. For example, in most business schools (including in developed countries) educators discuss business strategies and achievements undertaken mostly (if not exclusively) by male business leaders (role models). This needs to be changed, as there are now many examples of successful female-led firms in both developed and developing countries that could serve as insightful case studies in business schools. 


\section{References}

Abdulsaleh, A.M. and Worthington, A.C. (2013). Small and Medium-Sized Enterprises Financing: A Review of Literature. International Journal of Business and Management, 8(14): 36-54.

Abor, J. (2007). Industry Classification and the Capital Structure of Ghanaian SMEs. Studies in Economics and Finance, 24(3): 207-219.

Angelini P. \& A. Generale, 2005. "Firm Size Distribution: Do Financial Constraints Explain it All? Evidence from Survey Data", Bank of Italy Temi di Discussione (Working Paper) No. 549. Available at SSRN: http://ssrn.com/abstract=1015094

Alsos, Gry Agnete, Espen John Isaksen, and Elisabet Ljunggren (2006). New Venture Financing and Subsequent Business Growth in Men- and Women-Led Businesses. Entrepreneurship: Theory and Practice, 30(5):667-686.

Atanasova, C.V. and Wilson, N., 2004. Disequilibrium in the U.K. Corporate Loan Market. Journal of Banking and Finance, 28: 595-614.

Barbosa, E. G., and Moraes, C. C. (2003). Determinants of the firm's capital structure: The case of the very small enterprises. Retrieved on November 11, 2016 from http://econwpa.repec.org/ eps/fin/papers/0302/0302001.pdf

Bates, T. (1990). Entrepreneur human capital inputs and small business longevity. Review of Economics and Statistics, 72(4): 551-559.

Baydas M.M., Bahloul Z. and Adams D.W. (1995). Informal Finance in Egypt: «Banks within Banks', World Development, 23 (4), pp. 651-661.

Bougheas, S., Mizen, P. and Yalcin, Y., 2006. “Access to External Finance: Theory and Evidence on the Impact of Monetary Policy and Firm-Specific Characteristics," Journal of Banking and Finance, 30: 199-227.

Brixiová, Zuzana and Thierry Kangoye (2016). Gender and constraints to entrepreneurship in Africa: New evidence from Swaziland. Journal of Business Venturing Insights 5: 1-8

Ahl, H. (2006), 'Why Research on Women Entrepreneurs Needs New Directions', Entrepreneurship: Theory and Practice, 30(3): 595-621.

Asiedu, E., Kalonda-Kanyama, L. Leonce Ndikumana, and A. Akwasi Nti-Addae (2013). Access to credit by firms in Sub-Saharan Africa: How relevant is gender? American Economic Review, 103(3): 293-297.

Baliamoune, M. (2016) The Effectiveness of Foreign Aid to Women's Equality Organizations in the MENA, Journal of International Development, 28, 320-341.

Baliamoune-Lutz M. (2015). Gender economics in North Africa. In The Oxford Handbook of Africa and Economics, Monga C, Yifu Lin J (eds). Oxford University Press: Oxford, United Kingdom. 
Baliamoune-Lutz, M. (2011). 'Policy reform and entrepreneurship in developing countries', in Naudé, W.A. ed., Entrepreneurship in Economic Development, Palgrave Macmillan, 187-202. (also ICER)

Baliamoune-Lutz M, McGillivray M. (2009). Does gender inequality reduce growth in SubSaharan African and Arab countries? African Development Review, 21(2): 224-42.

Berger, A.N. and Udell, G.F. (1998) The Economics of Small Business Finance: The Roles of Private Equity and Debt Markets in the Financial Growth Cycle. Journal of Banking and Finance, 22, 613-673.

Blackden, M., and Mary Hallward-Driemeier (2013). Ready to Bloom? Finance \& Development (June), International Monetary Fund.

Brixiova, Z. (2010). Unlocking Productive Entrepreneurship in Africa's Least Developed Countries, African Development Review/Revue Africaine de Developpement, 22(3), 44051, http://onlinelibrary.wiley.com/journal/10.1111/\%28ISSN\%291467-8268/issues.

Brush, C., Carter, N., Greene, P., Gatewood, E., \& Hart, M. (2001). An investigation of women-led firms and venture capital investment. Report prepared for the U.S. Small Business Administration Office of Advocacy and the National Women's Business Council.

Cabral L.M.B. \& J. Mata (2003). On the Evolution of the Firm Size Distribution: Fact and Theory. American Economic Review, 93 (4): 1075-1090.

Carter, S. \& Rosa, P. (1998). The financing of male- and female-owned businesses. Entrepreneurship and Regional Development, 10(3): 225-241.

Coleman, S. (2000). Access to capital and terms of credit: A comparison of men- and womenowned small businesses. Journal of Small Business Management, 38(3): 37-52.

Coleman, S. (2007). The Role of Human and Financial Capital in the Profitability and Growth of Women-Owned Small Firms. Journal of Small Business Management, 45(3): 303-319.

Coleman, S. \& Carsky, M. (1996). Women Owned Businesses and Bank Switching: The Role of Customer Service. The Journal of Entrepreneurial and Small Business Finance, 5(1): $75-84$.

Cooley T. \& V. Quadrini (2001). Financial Markets and Firm Dynamics. American Economic Association, 91(5): 1286-1310.

Dezsö, Cristian, and Ross, David Gaddis (2012). Does female representation in top management improve firm performance? A panel data investigation. Strategic Management Journal, 33(9): 1072-1089.

EBRD (2015). EBRD launches Women in Business programme in Egypt. http://www.ebrd.com/news/2015/ebrd-launches-women-in-business-programme-inegypt.html, downloaded 25 September 2016.

Eldomiaty, Tarek I., T.I. \& E. K.A. Mohamed (2008). Is Debt Governance Structure Relevant to Firm Operating Performance in a Transitional Market? A Dynamic Approach, International Journal of Accounting and Finance, 1(2): 216-249.

Fabowale, L., Orser, R. \& Riding, A. (1995). Gender, structural factors, and credit terms between Canadian small businesses and financial institutions. Entrepreneurship Theory and Practice, 19(4), 41-65. 
Gertler, M. and Gilchrist, S., 1994. "Monetary Policy, Business Cycles, and the Behavior of Small Manufacturing Firms," Quarterly Journal of Economics, 109(2): 309-340.

González, R.L., J.A. Lopez, and J. Saurina (2007). Determinants of Access to External Finance: Evidence from Spanish Firms. Working Paper 2007-22, Federal Reserve Bank of San Francisco. http://www.frbsf.org/economic-research/files/wp07-22bk.pdf

Greene, P., Brush, C., Hart, M., \& Saparito, P. (2001). Patterns of venture capital funding: Is gender a factor? Venture Capital: An International Journal of Entrepreneurial Finance, 3(1): 63-83.

Gupta, Vishal K., Daniel B. Turban, S. Arzu Wasti, and Arijit Sikdar (2009). The Role of Gender Stereotypes in Perceptions of Entrepreneurs and Intentions to Become an Entrepreneur. Entrepreneurship: Theory and Practice, 33(2): 397-417.

Gupta, Vishal K., Daniel B. Turban, and Ashish Pareek (2013). Differences Between Men and Women in Opportunity Evaluation as a Function of Gender Stereotypes and Stereotype Activation. Entrepreneurship: Theory and Practice, 37(4): 771-788.

Haines, G.H., Orser, B.J., \& Riding, A.L. (1999). Myths and realities: An empirical study of banks and the gender of small business clients. Canadian Journal of Administrative Sciences, 16(4), 291-307.

Hall, G., P. Hutchinson and N. Michealas, 2000. Industry effect on the determinants of unquoted smes capital structure. International Journal of the Economic of Business, 7(3): 297-312.

Hallward-Driemeier, M. (2013), Enterprising Women: Expanding Economic Opportunities in Africa, Washington DC: World Bank.

Kashyap, A.K., Stein, J.C. and Wilcox, D.W. (1996). Monetary Policy and Credit Conditions: Evidence from the Composition of External Finance: Reply. American Economic Review, 86(1): 310-314.

Kasseeah, H., \& Thoplan, R. (2012). Access to Financing in a Small Island Economy: Evidence from Mauritius. Journal of African Business, 13(3): 221-231.

Kelley, D. J., C. G. Brush, P. G. Greene, Y. Litovsky \& Global Entrepreneurship Research Association (2013). Global Entrepreneurship Monitor: 2012 Women's Report. http://www.babson.edu/Academics/centers/blank-center/global-research/gem/ Documents/ GEM\%202012\%20Womens\%20Report.pdf.

Kounouwewa J. \& D. Chao (2011). Financing Constraints Determinants in African Countries. International Journal of Applied Economics and Finance, 5(1): 30-45.

Kumar, A. and M. Francisco (2005). Entreprise Size, Financing Patterns, and Credit Constraints in Brazil. World Bank Working Paper No. 49, The World Bank.

Kuntchev, Veselin, Rita Ramalho, Jorge Rodríguez-Meza and Judy S. Yang.(2013). What Have We Learned from the Enterprise Surveys regarding Access to Credit by SMEs? Policy Research Working Papers. DOI: http://dx.doi.org/10.1596/1813-9450-6670

Le, N.T.B., Venkatesh, S. and Nguyen, T.V. (2006) Getting Bank Financing: A Study of Vietnamese Private Firms. Asia Pacific Journal of Management, 23(2): 209-227.

Lutz, S. (2013). Risk premia in multi-national enterprises, North American Journal of Economics and Finance, 25, 293-305, http://dx.doi.org/10.1016/j.najef.2012.06.016. 
Lutz, S. (2012). Determination of market values and risk premia of multi-national enterprises and its application to transfer-pricing. International Business Research, 5(12), http://dx.doi.org/10.5539/ibr.v5n12p.

Majed, G. F. M., Alsharayri, A., \& Dandan, M. M. (2010). Impact of firm characteristic on Determining Financial Structure on the Insurance Sector Firms in Jordan. Journal of Social Sciences, 6(2): 282-286.

Marlow S. and Patton D. (2005) 'All Credit to Men? Entrepreneurship, Finance and Gender', Entrepreneurship Theory and Practice, 29 (6): 717-735.

Minniti, M. (2010), 'Female Entrepreneurship and Economic Activity', European Journal of Development Research, Vol. 22, 294-312.

Nakano, M. and Nguyen, P. (2011) Do Older Boards Affect Firm Performance? An Empirical Analysis Based on Japanese Firms. The Sixth Annual Conference on Asia-Pacific Financial Markets (CAFM), Seoul, Korea, 2 December. http://dx.doi.org/10.2139/ssrn.1879250

National Women's Business Council (2015). 10 Million Strong - The Tipping Point for Women's Entrepreneurship: 2015 Annual Report. https://www.nwbc.gov/sites/default/files/NWBC_2015 AnnualReportedited.pdf.

Ogubazghi, Kefleyesus Sebhatu and Willy Muturi, (2014). Journal: American Journal of Industrial and Business Management, 4(11): 632-643.

Orser, Barbara J., Allan L. Riding, and Kathryn Manley (2006). Women Entrepreneurs and Financial Capital. Entrepreneurship: Theory and Practice, 30(5): 643-665.

Orser, Barbara, Martine Spence, Allan Riding, and Christine A. Carrington (2010). Gender and Export Propensity. Entrepreneurship: Theory and Practice, 34(5): 933-957

Pagano, P., and F. Schivardi (2003). Firm Size Distribution and Growth. The Scandinavian Journal of Economics, 105(2): 255-274.

Painter, M. M. and K. Dobie (2010). Africa: Ethics and Sustainability within SMEs in SubSaharan Africa: Enabling, Constraining and Contaminating Relationships, Ethics in Small and Medium Sized Enterprises: A Global Commentary, 2010, 13-34.

Pandula, G. (2011) An Empirical Investigation of Small and Medium Enterprises' Access to Bank Finance: The Case of an Emerging Economy. ASBBS Annual Conference, Proceedings of ASBBS, Las Vegas, 18, 255-273.

Patrick, Amanda Elam, and Candida Brush (2013). Bank-Firm Relationships: Do Perceptions Vary by Gender? Entrepreneurship: Theory and Practice, 37(4): 837-858.

Quartey, P. (2003). Financing Small and Medium Enterprises (SMEs) in Ghana, Journal of African Business, 4(1): 2003, 37-55, http://www.tandfonline.com/loi/wjab20\#.

Rocha, R., et al. (2011). The status of bank lending to SMES in the Middle East and North Africa region: the results of a joint survey of the Union of Arab Bank and the World Bank, The World Bank, Policy Research Working Paper Series: 5607, http://wwwwds.worldbank.org/servlet/WDSContentServer/WDSP/IB/2011/03/24/000158349_201103 24082812/Rendered/PDF/WPS5607.pdf.

Rogerson, C. M. (2000). Successful SMEs in South Africa: The Case of Clothing Producers in the Witwatersrand, Development Southern Africa, 17(5), 687-716. 
Rugraff, E. and M.W. Hansen (eds.), 2011. Multinational Corporations and Local Firms in Emerging Economies, University of Chicago Press Economics Books, University of Saparito.

Saparito, Patrick, Amanda Elam, and Candida Brush (2013). Bank-firm relationships: Do perceptions vary by gender? Entrepreneurship: Theory and Practice, 37(4): 837-858.

Serrasqueiro, Z. and P. Nunes (2012). Is Age a Determinant of SMEs' Financing Decisions? Empirical Evidence Using Panel Data Models. Entrepreneurship: Theory and Practice, 36(4): 627-654.

Shinnar, Rachel S., Olivier Giacomin, and Frank Janssen (2012). Entrepreneurial Perceptions and Intentions: The Role of Gender and Culture. Entrepreneurship: Theory and Practice, 36(3): 465-493.

Smith, N., V. Smith, and M. Verner (2006). Do women in top management affect firm performance? A panel study of 2,500 Danish firms. International Journal of Productivity and Performance Management, 55(7): 569-593.

Sorooshian, S., Norzima, Z., Yusuf, I., \& Rosnah, Y. (2010). Structural Modeling of Entrepreneurships effectiveness. World applied Sciences Journal, 10(8), 923-929.

Tsai K.S. (2004) 'Imperfect Substitutes: The Local Political Economy of Informal Finance and Microfinance in Rural China and India', World Development, 32 (9): 1487-1507.

World Bank (2011), World Development Report 2012: Gender Equality and Development, Washington, DC: World Bank.

Yaldiz, E., Altunbas, Yener and Bazzana, Flavio. (2011). Determinants of Informal Credit Use: A Cross Country Study. Midwest Finance Association 2012 Annual Meetings Paper.Chicago Press: Chicago, IL. 


\section{Appendix}

\section{Table 1. Data source}

\begin{tabular}{|l|l|l|l|l|}
\hline$\#$ & Data type & Source & Downloaded / data & Date \\
\hline $\mathbf{1}$ & $\begin{array}{l}\text { African firm data } \\
\text { (balance sheet, } \\
\text { profit/loss) }\end{array}$ & $\begin{array}{l}\text { Bureau van Dijk } \\
\text { (BvD), Orbis } \\
\text { database }\end{array}$ & $\begin{array}{l}\text { German University in Cairo, } \\
\text { online license }\end{array}$ & $\begin{array}{l}\text { 3 December } \\
2015\end{array}$ \\
\hline
\end{tabular}

Product name
Update number
Software version
Data update
Username
Export date

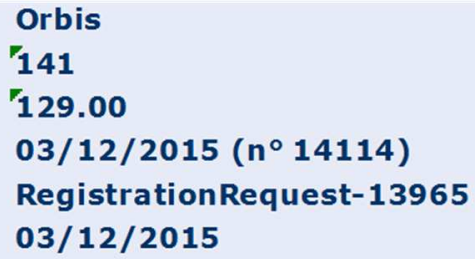

1. All active companies and companies with unknown situation

2. World region/Country/Region in country: Africa, MENA

3. Operating revenue (Turnover): All companies with a known value, 2015, 2014, 2013, 2012, 2011, 2010, $2009,2008,2007,2006$, for at least one of the selected periods, exclusion of companies with no recent financial data and Public authorities/States/Governments

4. P/L before tax: All companies with a known value, 2015, 2014, 2013, 2012, 2011, 2010, 2009, 2008, 2007,2006 , for at least one of the selected periods, exclusion of companies with no recent financial data and Public authorities/States/Governments 
Table 2. List of variables

\begin{tabular}{|c|c|}
\hline Variable & Definition \\
\hline BvD & Firm identifier (derived from BvD ID) \\
\hline Year & Year \\
\hline Country & Country \\
\hline Industry & NACE 2 Core Category (1 digit) \\
\hline BvDIndepIndic & BvD Independence Indicator \\
\hline BvDIndepA & BvDIndepIndic $=\mathrm{A}-, \mathrm{A}$, or $\mathrm{A}+$ \\
\hline ConsCode & Consolidation Code \\
\hline NoShareholders & Number of Recorded Shareholders \\
\hline NoSubsidiaries & Number of Recorded Subsidiaries \\
\hline GUOName & Global Ultimate Owner (GUO) Name \\
\hline GUODirectPct & GUO direct ownership share $(\%)$ \\
\hline GUOType & GUO type \\
\hline GUOCorp & GUO = Corporation \\
\hline GUOFamily & GUO = Family-owned \\
\hline GUOGovt & GUO = Government-owned \\
\hline GUOGender & GUO Gender \\
\hline GUOFemale & GUOGender $=$ Female \\
\hline LastAvailYear & Last Available Year \\
\hline NoEmployees & Number of Employees \\
\hline Revenue & Operating revenue (000`s USD) \\
\hline PLbeforTax & Profit/Loss before Tax (000`s USD) \\
\hline NetIncome & Net Income (000`s USD) \\
\hline Equity & Shareholder Funds (000`s USD) \\
\hline TotalAssets & Total Assets (000`s USD) \\
\hline Debt & Debt (000`s USD): TotalAssets - Equity \\
\hline ROE & Return on Equity (\%), use net Income \\
\hline Gearing & Gearing (\%), Debt / Equity \\
\hline $\ln *$ & Natural $\log \ln (*)$ of variable $\langle *\rangle$ \\
\hline a3* & 3 -period average a3 $(*)$ of variable $\langle *\rangle$ \\
\hline s3* & 3-period standard deviation $\mathrm{s} 3\left(^{*}\right)$ of variable $\left\langle^{*}\right\rangle$ \\
\hline FemaleGear & Interaction term: GUOFemale*Gearing \\
\hline FemaleShdf & Interaction term: GUOFemale* $\ln$ (Equity) \\
\hline FemaleDebt & Interaction term: GUOFemale* $\ln (\mathrm{Debt})$ \\
\hline FemaleA3Gear & Interaction term: GUOFemale*a3(Gearing) \\
\hline FemaleA3Shdf & Interaction term: GUOFemale*a3(ln(Equity)) \\
\hline FemaleA3Debt & Interaction term: GUOFemale* a3(ln(Debt)) \\
\hline Ins3PLbeforTax & Income risk measure: $\ln (\mathrm{s} 3$ (PLbeforTax) \\
\hline
\end{tabular}


Table 3.1. Summary statistics (selected variables)

\begin{tabular}{|c|c|c|c|c|c|}
\hline Variable & Obs & Mean & Std. Dev. & Min & Max \\
\hline Year & 229707 & & & 2006 & 2014 \\
\hline Country & 229707 & & & & 69 \\
\hline Industry & 203310 & 4.334351 & 1.881647 & $\mathbf{0}$ & 9 \\
\hline BvDIndepA & 229707 & .0411785 & .1987034 & $\mathbf{0}$ & 1 \\
\hline NoShareholders & 229707 & 2.285586 & 4.465129 & $\mathbf{0}$ & 122 \\
\hline NoSubsidiaries & 229707 & 2.481291 & 12.34119 & $\mathbf{0}$ & 591 \\
\hline GUOCorp & 229707 & .4133918 & .492443 & $\mathbf{0}$ & 1 \\
\hline GUOFamily & 229707 & .0116366 & .1072437 & $\mathbf{0}$ & 1 \\
\hline GUOGovt & 229707 & .0183364 & .134165 & $\mathbf{0}$ & 1 \\
\hline GUOFemale & 229707 & .0372997 & .1894956 & $\mathbf{0}$ & 1 \\
\hline GUODirectPct & 171612 & 91.41803 & 20.15072 & $\mathbf{0}$ & 100 \\
\hline GUOTotalPct & 136242 & 99.71207 & 3.286725 & 50.03 & 100 \\
\hline LastAvailYear & 229707 & 2012.817 & 1.249588 & 2011 & 2015 \\
\hline NoEmployees & 21426 & 1065.801 & 4914.384 & $\mathbf{0}$ & 143828 \\
\hline Revenue & 64200 & 303875.8 & 3312367 & -4900817 & $3.50 \mathrm{e}+08$ \\
\hline PLbeforTax & 31909 & 43011.33 & 277739.6 & -7871623 & $1.28 \mathrm{e}+07$ \\
\hline NetIncome & 16582 & 60387.22 & 356773.3 & -7976315 & $2.64 e+07$ \\
\hline Equity & 16839 & 481864.9 & 1848227 & -3195687 & $5.64 e+07$ \\
\hline TotalAssets & 16854 & 3378596 & $8.77 e+07$ & -10.61146 & $1.12 \mathrm{e}+10$ \\
\hline ROE & 8982 & 15.325 & 44.90861 & -995.397 & 966.607 \\
\hline Gearing & 6748 & 109.5777 & 149.672 & $\mathbf{0}$ & 996.425 \\
\hline
\end{tabular}


Table 3.2. Share of female-owned firms by country (1)

\begin{tabular}{|c|c|c|c|c|}
\hline Country & ISO Code & Obs & Mean & Std.Dev. \\
\hline United Arab Emirates & $\mathrm{AE}$ & 13086 & .0350757 & .1839781 \\
\hline Angola & $\mathrm{AO}$ & 117 & 0 & 0 \\
\hline Burkina Faso & $\mathrm{BF}$ & 108 & .0833333 & .2776739 \\
\hline Bahrain & $\mathrm{BH}$ & 1566 & .0344828 & .1825239 \\
\hline Burundi & $\mathrm{BI}$ & 9 & 0 & 0 \\
\hline Benin & BJ & 99 & 0 & 0 \\
\hline Botswana & $\mathrm{BW}$ & 396 & .0227273 & .1492212 \\
\hline Democratic Republic of Congo & $\mathrm{CD}$ & 135 & .1333333 & .3412007 \\
\hline Central African Republic & $\mathrm{CF}$ & 27 & 0 & 0 \\
\hline Congo & CG & 162 & 0 & 0 \\
\hline Cote D'Ivoire & CI & 477 & .0566038 & .2313265 \\
\hline Cameroon & $\mathrm{CM}$ & 684 & .0263158 & .1601898 \\
\hline Cape Verde & $\mathrm{CV}$ & 36 & 0 & 0 \\
\hline Djibouti & DJ & 18 & 0 & 0 \\
\hline Algeria & $\mathrm{DZ}$ & 756 & .0357143 & .1856997 \\
\hline Egypt & EG & 13014 & .0359613 & .1862008 \\
\hline Ethiopia & ET & 54 & 0 & 0 \\
\hline Gabon & GA & 135 & 0 & 0 \\
\hline Ghana & $\mathrm{GH}$ & 423 & .0212766 & .1444758 \\
\hline Gambia & GM & 54 & 0 & 0 \\
\hline Guinea & GN & 36 & 0 & 0 \\
\hline Guinea Bissau & GW & 27 & 0 & 0 \\
\hline Israel & IL & 82404 & .0360419 & .1863957 \\
\hline Iraq & IQ & 1125 & .008 & .0891238 \\
\hline Iran & IR & 684 & .0263158 & .1601898 \\
\hline Jordan & $\mathrm{JO}$ & 3546 & .0380711 & .1913949 \\
\hline Kenya & $\mathrm{KE}$ & 837 & .0215054 & .1451484 \\
\hline Comoros & $\mathrm{KM}$ & 9 & 0 & 0 \\
\hline Kuwait & KW & 4068 & .0995575 & .2994459 \\
\hline Lebanon & LB & 5256 & .0479452 & .2136707 \\
\hline Liberia & LR & 36 & 0 & 0 \\
\hline Lesotho & $\mathrm{LS}$ & 54 & 0 & 0 \\
\hline Libya & LY & 36 & 0 & 0 \\
\hline Morocco & MA & 11556 & .038162 & .1915955 \\
\hline Madagascar & $\mathrm{MG}$ & 81 & 0 & 0 \\
\hline Mali & ML & 108 & 0 & 0 \\
\hline Mauritania & MR & 45 & 0 & 0 \\
\hline Malta & MT & 41841 & .0189288 & .1362753 \\
\hline Mauritius & MU & 1485 & .0545455 & .2271673 \\
\hline Malawi & MW & 198 & 0 & 0 \\
\hline Mozambique & $\mathrm{MZ}$ & 153 & 0 & 0 \\
\hline Namibia & NA & 387 & 0 & 0 \\
\hline Niger & $\mathrm{NE}$ & 18 & 0 & 0 \\
\hline Nigeria & NG & 1314 & .0136986 & .116281 \\
\hline
\end{tabular}


Table 3.2. Share of female-owned firms by country (2)

\begin{tabular}{|l|c|c|c|c|}
\hline Country & ISO Code & Obs & Mean & Std.Dev. \\
\hline Oman & OM & 1620 & .0111111 & .1048544 \\
\hline Palestine & PS & 468 & .0384615 & .1925135 \\
\hline Qatar & QA & 1755 & .0461538 & .209878 \\
\hline Rwanda & RW & 81 & 0 & 0 \\
\hline Saudi Arabia & SA & 25020 & .0838129 & .2771126 \\
\hline Sudan & SD & 180 & 0 & 0 \\
\hline Sierra Leone & SL & 36 & 0 & 0 \\
\hline Senegal & SN & 918 & .0098039 & .0985819 \\
\hline South Sudan & SS & 18 & 0 & 0 \\
\hline Sao Tome and Principe & ST & 9 & 0 & 0 \\
\hline Syria & SY & 279 & .0322581 & .1770022 \\
\hline Swaziland & SZ & 72 & 0 & 0 \\
\hline Chad & TD & 36 & 0 & 0 \\
\hline Togo & TG & 99 & 0 & 0 \\
\hline Tunisia & TN & 612 & .0294118 & .1690959 \\
\hline Tanzania & TZ & 423 & .0212766 & .1444758 \\
\hline Uganda & UG & 189 & 0 & 0 \\
\hline Yemen & YE & 351 & 0 & 0 \\
\hline South Africa & ZA & 9702 & .0046382 & .0679498 \\
\hline Zambia & ZM & 522 & .0517241 & .221682 \\
\hline Zimbabwe & ZW & 621 & 0 & 0 \\
\hline
\end{tabular}


Table 3.3. Share of female-owned firms by industry

\begin{tabular}{|c|l|c|c|c|}
\hline NACE 2 & \multicolumn{1}{|c|}{ NACE 2 } & Obs & Mean & Std.Dev. \\
\hline 0 & $\begin{array}{l}\text { Agriculture, Forestry, Fishing, } \\
\text { Mining, Quarrying }\end{array}$ & 3771 & .0190931 & .1368704 \\
\hline 1 & $\begin{array}{l}\text { Manufacture, food products, } \\
\text { beverages, etc }\end{array}$ & 11349 & .036479 & .187487 \\
\hline 2 & $\begin{array}{l}\text { Manufacture, chemicals, } \\
\text { pharmaceuticals, etc }\end{array}$ & 22491 & .0232093 & .150571 \\
\hline 3 & $\begin{array}{l}\text { Manufacture, transport } \\
\text { equipment, machinery, } \\
\text { furniture, etc }\end{array}$ & 5373 & .0217755 & .1459635 \\
\hline 4 & $\begin{array}{l}\text { Construction, wholesale, retail } \\
\text { trade }\end{array}$ & 92169 & .0584904 & .2346697 \\
\hline 5 & Transport & 8721 & .0206398 & .1421835 \\
\hline 6 & Media, broadcasting & 34416 & .0180439 & .1331122 \\
\hline 7 & $\begin{array}{l}\text { Services, management, } \\
\text { consulting }\end{array}$ & 14787 & .0316494 & .1750709 \\
\hline 8 & Services, other & 5616 & .0352564 & .1844436 \\
\hline 9 & Services arts, entertainment & 4617 & .0389864 & .1935834 \\
\hline & & & & \\
\hline
\end{tabular}


Table 3.4. Key financial indicators: Female vs other firms

\begin{tabular}{|c|c|c|c|c|c|c|}
\hline Indicator & & Obs & Mean & Std.Dev. & Min & $\max$ \\
\hline \multirow[t]{2}{*}{ Equity } & All firms & 16839 & 481864.9 & 1848227 & -3195687 & $5.64 \mathrm{e}+07$ \\
\hline & $\begin{array}{l}\text { Female- } \\
\text { owned }\end{array}$ & 203 & 143995.8 & 1238093 & -10647.65 & $1.76 e+07$ \\
\hline \multirow[t]{2}{*}{ Debt } & All firms & 16757 & 2651590 & $8.70 \mathrm{e}+07$ & .0500461 & $1.12 \mathrm{e}+10$ \\
\hline & $\begin{array}{l}\text { Female- } \\
\text { owned }\end{array}$ & 200 & 342703.2 & 2072611 & 25.1991 & $2.76 e+07$ \\
\hline \multirow[t]{2}{*}{ Gearing } & All firms & 6748 & 109.5777 & 149.672 & 0 & 996.425 \\
\hline & $\begin{array}{l}\text { Female- } \\
\text { owned }\end{array}$ & 56 & 83.4762 & 116.2051 & 0 & 734.751 \\
\hline \multirow[t]{2}{*}{ Revenue } & All firms & 64200 & 303875.8 & 3312367 & -4900817 & $3.50 \mathrm{e}+08$ \\
\hline & $\begin{array}{l}\text { Female- } \\
\text { owned }\end{array}$ & 1699 & 161322.2 & 3098537 & -9254.373 & $1.20 \mathrm{e}+08$ \\
\hline \multirow[t]{2}{*}{ PLbeforTax } & All firms & 31909 & 43011.33 & 277739.6 & -7871623 & $1.28 \mathrm{e}+07$ \\
\hline & $\begin{array}{l}\text { Female- } \\
\text { owned }\end{array}$ & 453 & 7616.461 & 22113.76 & -24081.69 & 172495 \\
\hline \multirow[t]{2}{*}{ NetIncome } & All firms & 16582 & 60387.22 & 356773.3 & -7976315 & $2.64 \mathrm{e}+07$ \\
\hline & $\begin{array}{l}\text { Female- } \\
\text { owned }\end{array}$ & 207 & 5983.08 & 16205.15 & -24018.31 & 72091 \\
\hline \multirow[t]{2}{*}{ ROE } & All firms & 8982 & 15.325 & 44.90861 & -995.397 & 966.607 \\
\hline & $\begin{array}{l}\text { Female- } \\
\text { owned }\end{array}$ & 80 & 14.26438 & 21.51995 & -103.808 & 77.534 \\
\hline
\end{tabular}


Table 4.1. Preliminary results: Revenues and profits (Pooled OLS estimations)

\begin{tabular}{|c|c|c|c|}
\hline Model & (4.1.1) OLS & (4.1.2) OLS & (4.1.3) OLS \\
\hline Dep. Variable & InRevenue & InPLbeforTax & InNetIncome \\
\hline l.a3InEquity & $0.660 * * *$ & $0.726 * * *$ & $0.803 * * *$ \\
\hline l.a3Gearing & $0.000000038 * * *$ & $0.000000038^{* * *}$ & $0.00000041 * * *$ \\
\hline GUOFemale & $-0.191 *$ & $-0.487 * * *$ & $-0.495 * * *$ \\
\hline & & & \\
\hline Observations & 18709 & 15186 & 7772 \\
\hline R-sq. & 0.5167 & 0.6598 & 0.7377 \\
\hline R-sq. adj. & 0.5167 & 0.6598 & 0.7376 \\
\hline Prob > F & 0.0000 & 0.0000 & 0.0000 \\
\hline
\end{tabular}

Notes.

(i) All models estimated with pooled OLS.

(ii) All models include a constant. All models include country, industry, and year dummies.

(iii) $* * *$ denotes significant at the $1 \%, * *$ at the $5 \%, *$ at the $14 \%$ level. 
Table 4.2. Results summary: Revenues, profits, and returns (Pooled OLS estimations)

\begin{tabular}{|c|c|c|c|c|}
\hline Model & (4.2.1) OLS & (4.2.2) OLS & (4.2.3) OLS & (4.2.4) OLS \\
\hline Dep. Variable & InRevenue & InPLbeforTax & InNetIncome & ROE \\
\hline l.a3InEquity & 0.653 *** & $0.707 * * *$ & $0.749 * * *$ & $-3.548 * * *$ \\
\hline l.a3Gearing & $0.000000037 * * *$ & $0.000000035^{* * *}$ & $0.0000016^{* * *}$ & $0.00012 * * *$ \\
\hline GUOFemale & $-1.252 * *$ & $-2.228 * * *$ & $-1.842 * * *$ & $-104.1 *$ \\
\hline I.FemaleA3Shfd & $0.083^{*}$ & $0.179 * * *$ & $0.151 * *$ & $8.318^{*}$ \\
\hline I.FemaleA3Gear & $0.00012 * * *$ & $0.00013 * * *$ & $0.00014 * * *$ & 0.0042 \\
\hline BvDIndepA & $-0.372 * * *$ & $-0.285^{* * *}$ & $-0.261 * * *$ & $-6.718 * * *$ \\
\hline NoShareholders & $0.036 * * *$ & $0.045 * * *$ & $0.029 * * *$ & $0.496 * * *$ \\
\hline NoShareholders ${ }^{\wedge} 2$ & $-0.00025^{* * *}$ & $-0.00034 * * *$ & $-0.00023^{* * *}$ & $-0.0037 * * *$ \\
\hline Observations & 17654 & 14356 & 7534 & 6597 \\
\hline R-sq. & 0.5826 & 0.6887 & 0.7689 & 0.0884 \\
\hline R-sq. adj. & 0.5805 & 0.6868 & 0.7662 & 0.0790 \\
\hline Prob $>$ F & 0.0000 & 0.0000 & 0.0000 & 0.0000 \\
\hline
\end{tabular}

Notes.

(i) All models estimated with pooled OLS.

(ii) All models include a constant. All models include country, industry, and year dummies.

(iii) $* * *$ denotes significant at the $1 \%, * *$ at the $5 \%, *$ at the $10 \%$ level. 
Table 4.3. Results summary: Revenues, profits, and returns (RE estimations)

\begin{tabular}{|c|c|c|c|c|}
\hline Model & (4.3.1) RE & (4.3.2) RE & $(4.3 .3) \mathrm{RE}$ & (4.3.4) RE \\
\hline Dep. Variable & InRevenue & InPLbeforTax & InNetIncome & ROE \\
\hline l.a3InEquity & $0.424 * * *$ & $0.584 * * *$ & $0.654 * * *$ & $-5.595 * * *$ \\
\hline l.a3Gearing & $0.000000022 * * *$ & $0.000000021 * * *$ & $0.00000051 * * *$ & 0.000065 \\
\hline GUOFemale & $-1.325 * * *$ & $-1.855 * *$ & $-2.215 * *$ & -95.39 \\
\hline I.FemaleA3Shfd & 0.066 & $0.134 *$ & $0.188^{*}$ & 5.550 \\
\hline l.FemaleA3Gear & $0.00016^{* * *}$ & $0.00010 * *$ & $0.00014 * * *$ & $0.040 * *$ \\
\hline BvDIndepA & $-0.423 * * *$ & $-0.286 * * *$ & $-0.252 * * *$ & $-8.211 * * *$ \\
\hline NoShareholders & $0.056 * * *$ & $0.054 * * *$ & $0.042 * * *$ & $0.482 * *$ \\
\hline NoShareholders $^{\wedge} 2$ & $-0.00037 * * *$ & $-0.00040 * * *$ & $-0.00032 * * *$ & -0.0030 \\
\hline Observations & 17654 & 10595 & 7534 & 6597 \\
\hline Groups (Firms) & 3355 & 2981 & 2550 & 1083 \\
\hline R-sq. within & 0.0360 & 0.0264 & 0.0054 & 0.0128 \\
\hline R-sq. between & 0.5748 & 0.7189 & 0.7415 & 0.1809 \\
\hline R-sq. overall & 0.5493 & 0.7064 & 0.7565 & 0.0833 \\
\hline Prob > chi2 & 0.0000 & 0.0000 & 0.0000 & 0.0000 \\
\hline
\end{tabular}

Notes.

(i) All models estimated with random effects.

(ii) All models include a constant. All models include country, industry, and year dummies.

(iii) $* * *$ denotes significant at the $1 \%$, ** at the $5 \%, *$ at the $13 \%$ level. 
Table 4.4. Results summary: Revenues, profits, and returns (RE estimations)

\begin{tabular}{|c|c|c|c|c|}
\hline Model & $(4.4 .1) \mathrm{FE}$ & $(4.4 .2) \mathrm{FE}$ & $(4.4 .3) \mathrm{FE}$ & $(4.4 .4) \mathrm{FE}$ \\
\hline Dep. Variable & InRevenue & InPLbeforTax & InNetIncome & ROE \\
\hline l.a3InEquity & $0.194 * * *$ & $0.153 * * *$ & 0.041 & $-8.290 * * *$ \\
\hline l.a3Gearing & -0.0000000010 & -0.000000012 & 0.0000000012 & $-0.00011^{*}$ \\
\hline l. Ins3PLbeforTax & $0.089 * * *$ & $0.113 * * *$ & $0.050^{* * *}$ & $3.732 * * *$ \\
\hline I.FemaleA3Shfd & -0.104 & -0.224 & -0.144 & -3.968 \\
\hline I.FemaleA3Gear & $0.00020 * * *$ & $0.00015 * *$ & 0.000087 & $0.092 * * *$ \\
\hline Observations & 18558 & 15170 & 7769 & 6606 \\
\hline Groups (Firms) & 3628 & 3413 & 2725 & 1085 \\
\hline R-sq. within & 0.0448 & 0.0205 & 0.0131 & 0.0180 \\
\hline R-sq. between & 0.3619 & 0.5052 & 0.6039 & 0.1080 \\
\hline R-sq. overall & 0.3960 & 0.5233 & 0.6181 & 0.0443 \\
\hline Prob > chi2 & 0.0000 & 0.0000 & 0.0000 & 0.0000 \\
\hline
\end{tabular}

Notes.

(i) All models estimated with fixed effects.

(ii) All models include a constant. All models include year dummies.

(iii) $* * *$ denotes significant at the $1 \%, * *$ at the $5 \%, *$ at the $10 \%$ level. 
Table 4.5. Results summary: Female Ownership, Financing (IV estimations)

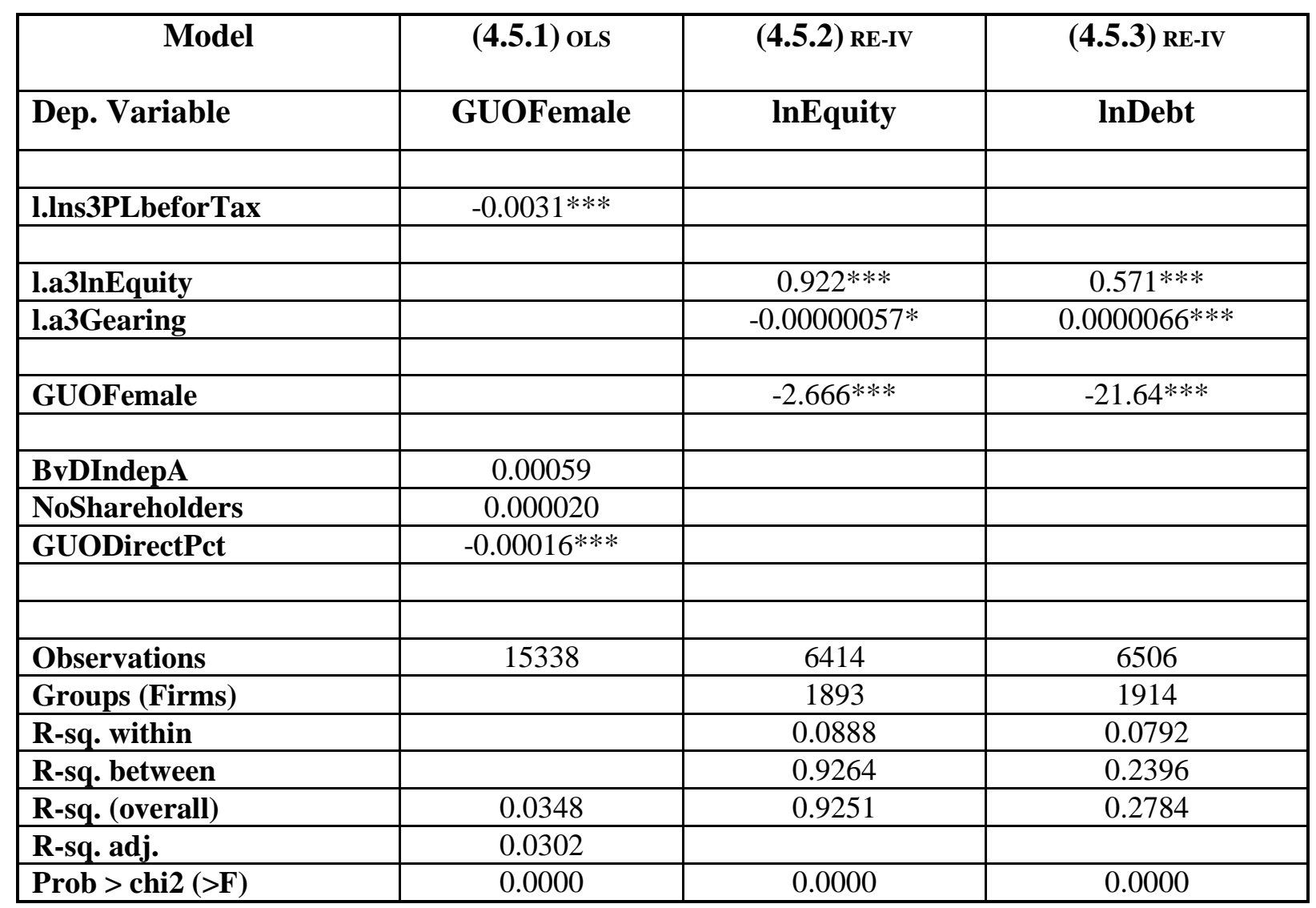

Notes.

(i) Model (1) estimated with pooled OLS; Models (2), (3) estimated with random effects IV regression; GUOGender instrumented by BvDIndepA, NoShareholders, GUODirectPct, lns3PLbeforTax, I.Conscode, I.LastAvailYear, I.Country, I.Industry, I.Year.

(ii) All equations include a constant; all equations include year dummies; equation (1) includes dummies for country, industry, ConsCode, and LastAvailYear.

(iii) $* * *$ denotes significant at the $1 \%, * *$ at the $5 \%, *$ at the $19 \%$ level. 
Table 4.6. Results summary: Revenues, profits, and returns (IV estimations)

\begin{tabular}{|c|c|c|c|}
\hline Model & (4.6.1) RE-IV & (4.6.2) RE-IV & (4.6.3) RE-IV \\
\hline Dep. Variable & InRevenue & InPLbeforTax & InNetIncome \\
\hline l.a3InEquity & $0.493 * * *$ & $0.624 * * *$ & $0.738 * * *$ \\
\hline l.a3Gearing & $0.0000021^{* * *}$ & $0.0000026^{* * *}$ & $0.0000057 * * *$ \\
\hline GUOFemale & $-37.27 * * *$ & $-89.51 * * *$ & $-63.60 * * *$ \\
\hline I.FemaleA3Shfd & $3.524 * * *$ & $8.314 * * *$ & $5.886^{* * *}$ \\
\hline I.FemaleA3Gear & $0.0069 * * *$ & $0.0071 * * *$ & $0.044 * * *$ \\
\hline Observations & 10652 & 8616 & 5289 \\
\hline Groups (Firms) & 2218 & 2082 & 1739 \\
\hline R-sq. within & 0.0347 & 0.0043 & 0.0038 \\
\hline R-sq. between & 0.4015 & 0.3815 & 0.5373 \\
\hline R-sq. overall & 0.3740 & 0.3536 & 0.5709 \\
\hline Prob > chi2 & 0.0000 & 0.0000 & 0.0000 \\
\hline
\end{tabular}

Notes.

(i) All models estimated with random effects IV regression; GUOGender instrumented by BvDIndepA, NoShareholders, GUODirectPct, Ins3PLbeforTax, I.Conscode, I.LastAvailYear, I.Country, I.Industry, I.Year.

(ii) All equations include a constant; all equations include year dummies.

(iii) $* * *$ denotes significant at the $1 \%, * *$ at the $5 \%, *$ at the $10 \%$ level. 